\title{
Aletic Republic - A Fictional World as Inspiration for the Real World Beyond Borders
}

In our everyday life, as we work or travel, we are always confronted with many kinds of borders: political ones when we travel to other countries, or cultural ones, when we meet people with different backgrounds or life styles. We generally take these borders as something natural or let alone as something sacrosanct. And although in the Western civilization, we are aware of the fact that we have big difficulties in accepting the other's point of view or her way of life, we rather reinforce the borders and isolate ourselves from influences alien for our traditional or so-called pristine world.

How could people of different cultures, religions, or languages manage to live together in the most harmonic way possible? Music is one kind of art which inspires and unites people across borders, but so does imagination: Aletic Republic as a fictional republic transcends a world from imagination into a more tangible place full of persons, landscapes, stories, poetry, and moods.

\section{The Beginning: Creation of a Fictional World}

Let me take you on a short trip back to your childhood. Do you still remember the area around your home where you used to play with your friends? How did it look like? What kind of objects did you engage with in your games, both outside and at home? In retrospect: did your world, i.e. the place around your home, look like it really was? Maybe, as you grew older, moved out, and came back to your first home visiting your family, you realized that now all those objects looked different from your point of view as an adult. 


\section{Selim Özgür}

In an analogous manner, when you try to remember your first book - with simple sentences or illustrations only - how did the content look or feel like? Maybe you could not understand the sentences let alone distinguish the differently shaped characters as letters - but the book certainly stimulated your imagination: what are these colors and shapes trying to tell me? Probably your imagination got influenced by various circumstances, e.g. someone in your family reading you the book out, the surrounding voices and sounds or some particular food or drink you had while you were focused on the book.

In our adulthood, we seldom try to think back and remember the mentioned way of perceiving the world, despite it being our very first and thus our most pristine and essential one.

I still remember quite a lot of these impressions from the first years of my life and recollect how my imagination was expand-

\section{PROVINZEN DER ALETISCHEN REPUBLIK}

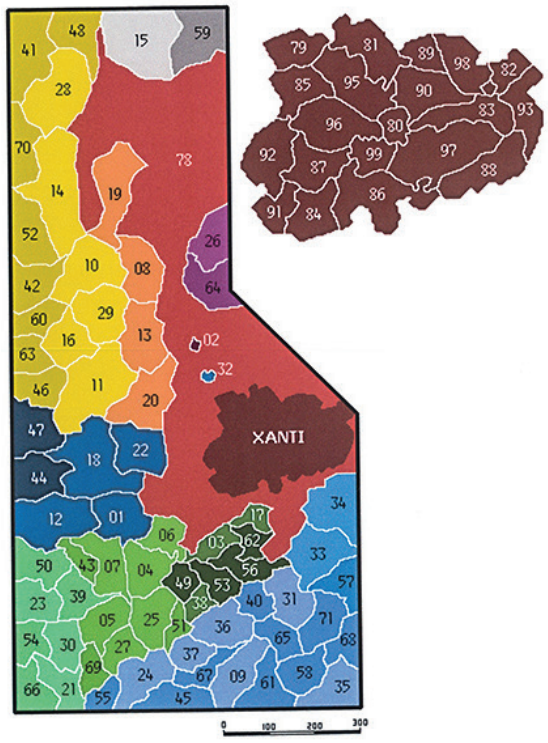

Argala

Axane

Battelndottel

Bena

Bollo

Coculi

Dalos

Dillin

Eulernause

Esquival

Eftringen

Fauslenner

Gnippenburg

Grotula

Hirolana

Hohlenneuburs

Homul

Intercityfelo

Itti

Kenastenburg

Kifs

Kifs
Keftitana

Mafowope

Neu-Bena

Noquayna

Palonia

Rufun

Sifnofona

Savisa

Tilim

Vaslait

Veslep

Wadalen

Weidermuntern

Antafenoxi

Attimana

Ayga

Curcu

Dorigodolo

Farragul

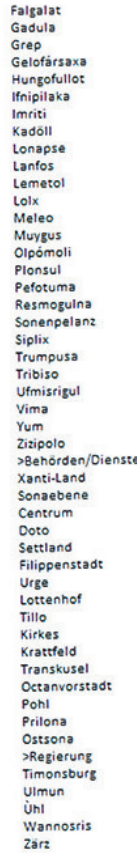


ing. My room was divided by me and my sibling with a virtual line across it, and by the time I would start going to school, I had defined the space belonging to me as my own empire. Only during my adolescence, I started seriously creating a fictional country from out of my area. The shape of the room's section is still visible on the silhouette of Aletic Republic.

During adolescence, I often focused on my fictional republic and felt the urge to create something exceeding a mere idea from childhood. As my conviction was firm, I started to deduct the topography of the republic by looking at the furniture and its dimensions. The following step was the creation of provinces and the invention of their names. One of the crucial aspects of this creative process was the ability to shape and name cities and provinces according to my own imagination and mood, protected from any criticism.

\section{Aletic Republic: Creating an Inner Identity}

After I finished the main shape of the republic, i.e. the general topography, provinces and cities, the project was still far from reaching its end. Following my conviction, I wanted to animate this world. I had to zoom into this world and discover more details. Not only were these details limited to many citymaps I started to draw, they also led to the invention of a history and own language with its own alphabet: the Aletic. The vocabulary contains around two thousand words so far and is still being extended. One of the main differences between Aletic Republic and many other fantasy worlds, such as the one in The Lord of the Rings by J.R.R. Tolkien, consists in the temporal location of my world in the twentieth and twenty-first centuries. The people and objects in Aletic Republic are contemporary: people with mobile phones, traveling on buses and in subway, having a coffee in a bar on the boulevard - following one of the aims of this project: to create a fictional world where contemporary problems and ideas can take place and can be discussed. Nevertheless, there is a map depicting a simulated historical map of the capital city in order to make this image more profound. 


\section{Selim Özgür}
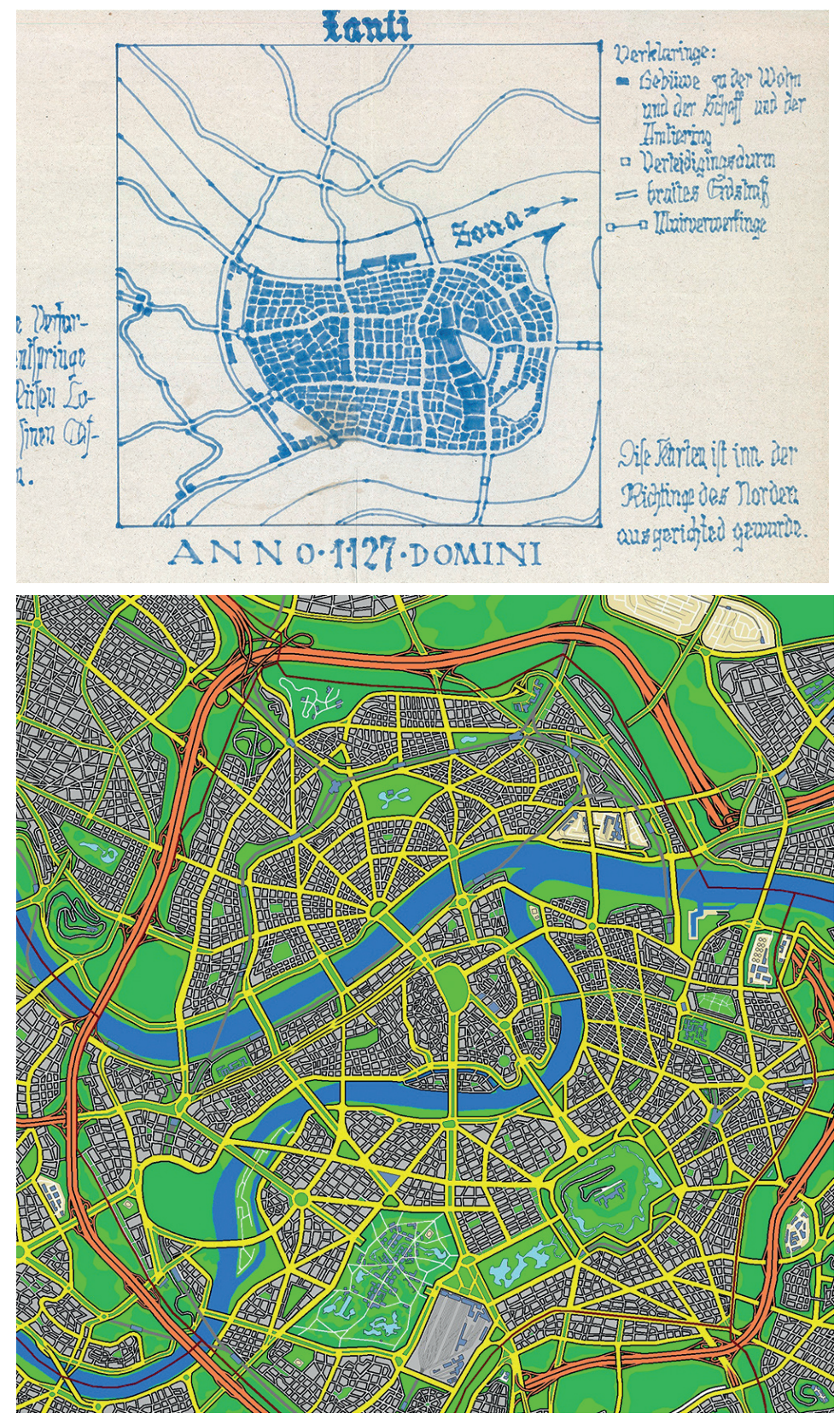


\section{Tilim - Public Transportation Network Map and Timetable}

The city of Tilim, the capital of the homonymous province, serves as a prototype project of my network plannings. Unlike in real cities, where public transportation network grows step by step, more or less following the pace of the urban growth, the network of Tilim is developed in retrospect. The first step was to imagine the city in its dimensions and with its peculiar topography. This imaginary topography led me to the next step wondering about how many people live there, where the centers of the disctricts are located, how the architecture of each district looks like, and finally, how the network itself can provide good and efficient connections within the urban area.

The planning of the first lines, now being the most important lines of the current version of the network, started around 2005, and by constantly adding more lines to the network and changing routes, the network reached its peak in 2009, with minor changes followed in the coming years. Having reached the peak in 2009, the network consisted of 28 tram lines, 22 bus lines, and 3 metro lines.

During the first years of constant extension - as the network was taking shape - the only representing object of the city of Tilim was this network map. In my mind, however, I envisioned - and continue to envision - the image of the city, how its copes with its topography, and what kind of interactions occur between hills, parks, buildings, waters, streets, and people. These aspects, however, are not displayed in the simple diagram I created. I felt the urge to find a way to transcend the border between my expanding imagination and the limited possibilities provided by the sheet of paper and its two dimensions.

Consequently, I started drawing city map details of the central areas of some districts, which allows the observer to discover the names of many streets, important buildings such as cultural institutions or university buildings, as well as try to deduct the topogaphical shape, i.e. rises and slopes, as some street names or neigh- 


\section{Selim Özgür}

borhood names allow us to do. The observer's imagination cannot converge with the author's, but nevertheless it may approach the authentic version that exists in the author's imagination. The more experienced the observer is, i.e. if she has traveled to many different cities and is familiar with reading city maps, the more these real life experiences can help her build a connection between the depicted streets and the topogrpahical aspects in the map she is observing, on the one hand, and the author ${ }^{6} \mathrm{~s}$ intention on the other.

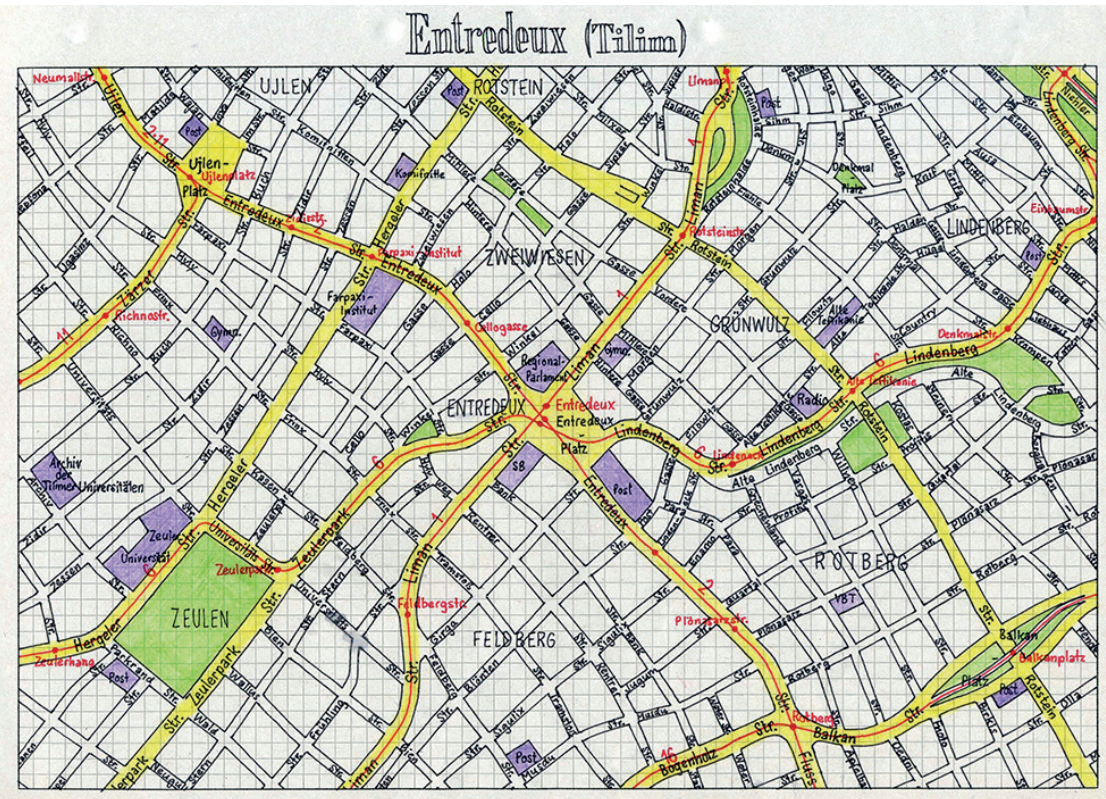

In 2011, I created a document containing of 107 pages, where I provided the integral timetable of the network, line by line. The 2011 version replaced the first 2007 version which was a small handwritten booklet of about 130 pages. The major change in the newer version - disregarding its digital vform - was the introduction of non-stop operation time. Due to the network's density, the good connectedness between all districts and the 24/7 operation times, I decided to introduce another drastic change for this city: since the public transportation services need to be used to their full 
capacity, not only the frequency on major lines should not fall below 10 minutes - allowing to still maintain a higher and well harmonized frequency on tracks serviced by more lines - all private traffic within the city has been reestablished. Of course, there are some exceptions for taxis, deliveries, or emergency services.

The aim of this change was to offer a dialogue: first, to make the observer accept the idea of a metropolis possibly living and functioning without cars - with the exceptions shown. The second step would be to let this idea settle down. Maybe, the evoked discussion can be held differently if we suggest introducing these incisive measures in a real, existing city; so far, the discussion would only remain within the framework of the fictional world.

There are more projects which have been implemented on the basis of this network, such as drawing maps of other parts of the city, drawing overview maps of tram tracks at certain stations, or animating the map by writing stories that took place in this city, or creating fictive transportation tickets.

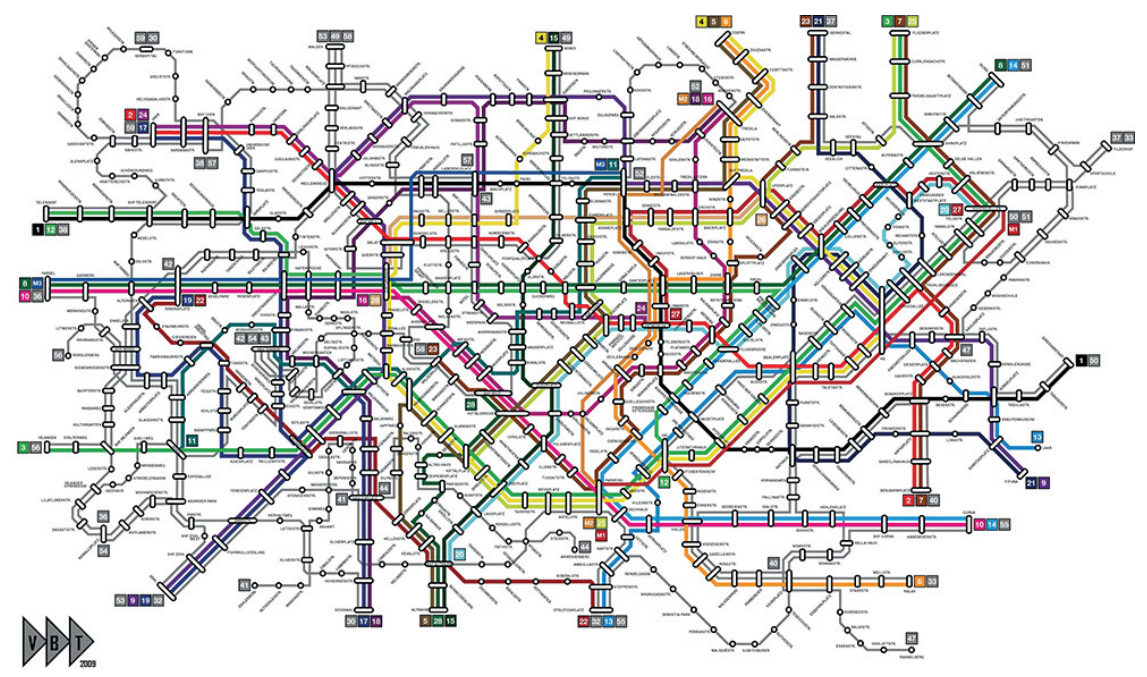




\section{4}

\section{Ihen $\rightarrow$ Entredeux}

via Bhf Ihen, Weilerkreuz, Waldgangplatz,

Laderohlplatz, Bhf Laderohl, Botel, Bhf Ujlen

Grundkurs:

Ihen

$00 \quad 0510 \quad 1520 \quad 2530 \quad 3540 \quad 4550 \quad 55$

Bhf Ihen

$\begin{array}{llllllllllll}02 & 07 & 12 & 17 & 22 & 27 & 32 & 37 & 42 & 47 & 52 & 57\end{array}$

Weilerkreuz

$1015202530 \quad 3540 \quad 45505500 \quad 05$

Waldgangplatz $15 \quad 2025 \quad 3035 \quad 4045 \quad 5055 \quad 0005 \quad 10$

Laderohlplatz $20 \quad 2530 \quad 3540 \quad 4550 \quad 5500 \quad 0510 \quad 15$

Bhf Laderohl $\quad 212631 \quad 36414651 \quad 5601 \quad 0611 \quad 16$

Botel $\quad 242934394449545904091419$

Bhf Ujlen $\quad 313641 \quad 46515601 \quad 0611 \quad 162126$

Entredeux $\quad 36 \quad 4146 \quad 5156 \quad 0106 \quad 11162126 \quad 31$

$\begin{array}{llllll}C & C & C & C & C & C\end{array}$

Spezialkurse:

$\begin{array}{lcc}\text { Ihen } & \mid & 15 \\ \text { Weilerkreuz } & \mid & 25 \\ \text { Birkenplatz } & 26 & 32 \\ \text { Botel } & 29 & \text { | } \\ \text { Entredeux } & 41 & \text { | } \\ & \text { A } & \text { B }\end{array}$

Die C-Kurse verkehren wie folgt:

$\begin{array}{ll}\text { Mo-Fr: } & 515-2105 \\ \text { Sa: } & 615-2005 \\ \text { So: } & 715-2005\end{array}$

Bitte die Spezialkurse beachten:

A-Kurse:

B-Kurse:

Mo-Fr: ab $526 \quad$ Mo - Fr: ab 2115

Sa: $\quad$ ab 626 Sa: $\quad$ ab 2015

So: $\quad$ ab 726 So: $\quad$ ab 2015

Zwischen 2110 (Mo-Fr) bzw. 2010 (Sa-So) und 510 (Mo-Fr) bzw. 610 (Sa) bzw. 710 (So) verkehren die Kurse durchgehend nach dem Grundkurs im 10'-Takt. 


\section{A possible outlook}

This project has now been alive for almost thirty years - and yet is not complete. Aletic Republic, with all its facets, has an almost infinite capacity for creating new subprojects, such as writing stories, drawing different kind of maps, or inventing more words. It has always been enriching my life, inspiring me to learn and improve new skills as well as developing my creativity. Despite having invented this world mainly for myself, I believe that future collaboration with other fields or projects can lead to mutual enrichment of all participants.

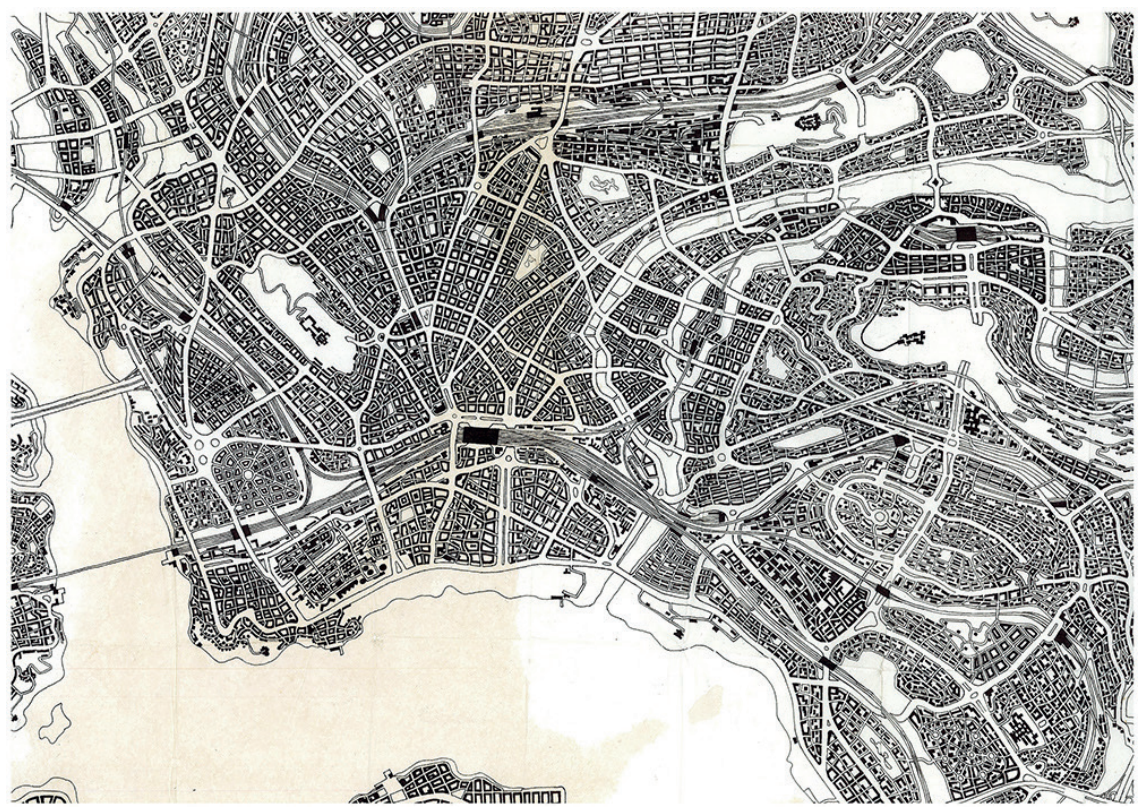




\section{Summary}

In our everyday life, as we work or travel, we are always confronted with many kinds of borders: political ones when we travel to other countries, or cultural ones, when we meet people with different backgrounds or lifestyles. We generally take these borders as something natural or let alone as something sacrosanct. And although in the Western civilization, we are aware of the fact that we have big difficulties in accepting the other's point of view or her way of life, we rather reinforce the borders and isolate ourselves from influences alien for our traditional or so-called pristine world. How could people of different cultures, religions, or languages manage to live together in the most harmonic way possible? Music is one kind of art which inspires and unites people across borders, but so does imagination: The Aletic Republic as a fictional republic transcends a world from imagination into a tangible place full of persons, landscapes, stories, poetry, and moods.

Keywords: borders, stereotypes, the Aletic Republic, an imagining world, place of harmony.

\section{Аннотация}

\section{Селим Озгюр}

Алетическая республика: вымышленный мир как источник вдохновения для реального мира поверх границ

В нашей повседневной жизни мы всегда сталкиваемся со многими видами границ: политическими, когда мы путешествуем в другие страны, или культурными, когда мы встречаем людей с разным происхождением или стилем жизни. Обычно мы воспринимаем эти границы как нечто естественное или как нечто сакральное. И хотя в западной цивилизации мы осознаем тот факт, что у нас есть большие трудности в принятии точки зрения другого или его образа жизни, мы скорее укрепляем границы и изолируем себя от влияний, чуждых нашим тради- 
ционным мирам. Как могли бы люди, принадлежащие к разным культурам, религиям или языкам, жить вместе наиболее гармоничным образом? Музыка - это один из видов искусства, который вдохновляет и объединяет людей, не знающих границ, как и воображение: Алетическая республика как вымышленная республика переводит мир из воображения в осязаемое место, полное людей, природы, насыщенное историй, поэзией и эмоциями.

Ключевые слова: границы, стереотипы, Алетическая республика, воображаемый мир, гармония. 